\section{Military hit by brain drain}

\section{London}

THF: Soviet armed forces are suffering from a temporary but acute brain-drain, Defence Minister General Dmitrii Yazov told an Izvestiya interviewer last week. The shortage, he said, is due to the early demobilization of students who had been called up for military service. Since for the most part student-draftees were assigned to jobs requiring a high level of technical expertise, their premature departure leaves serious gaps. More than 700 tanks and 900 infantry combat vehicles will be left without crews, and the rocket forces will have to go on to a watch-and-watch system instead of the present watch in three. It will take at least a year for the army and two years for the navy to make up the deficit.

The decision to release the students ahead of time came after several years' campaigning from rectors and faculty members of universities and higher education institutes who pointed out that national service interrupted a young man's career just when he was at the peak of intellectual creativity. Army service, they maintained, spoiled him for a scientific career, without for the most part making a good soldier out of him. The early demobilization of the students was widely hailed as the first step in the plan to reduce the Soviet armed forces by 500,000 men. Yazov now says, however, this is not so. The cuts, he explained, are being made by reducing the annual size of the draft HIPPARCOS

\section{Rescue nearly over}

\section{Munich}

Preliminary results obtained last week demonstrated that the European Space Agency (ESA) astrometry satellite Hipparcos will yield some data, if not as much as originally planned. The perigee of Hipparcos's still very elliptical orbit (see Nature 341,$3 ; 1989$ ) has been increased to $526 \mathrm{~km}$ above the Earth's surface, and its rotation has been stopped. ESA was intending to remove the protective baffles from the telescope aperture on 26 September.

On-board tests have indicated that the telescope and its instrumentation appear to be working. Except during the satellite's passage through the Van Allen radiation belts, $5,000 \mathrm{~km}$ above the Earth, the telescope's response was as expected, suggesting that Hipparcos will be able to return useful data 90 per cent of the time. Once the baffles are removed, it will be four weeks before ESA can gauge accurately the length of the mission. The current best estimate is that Hipparcos will survive six months, compared with the planned duration of two years.
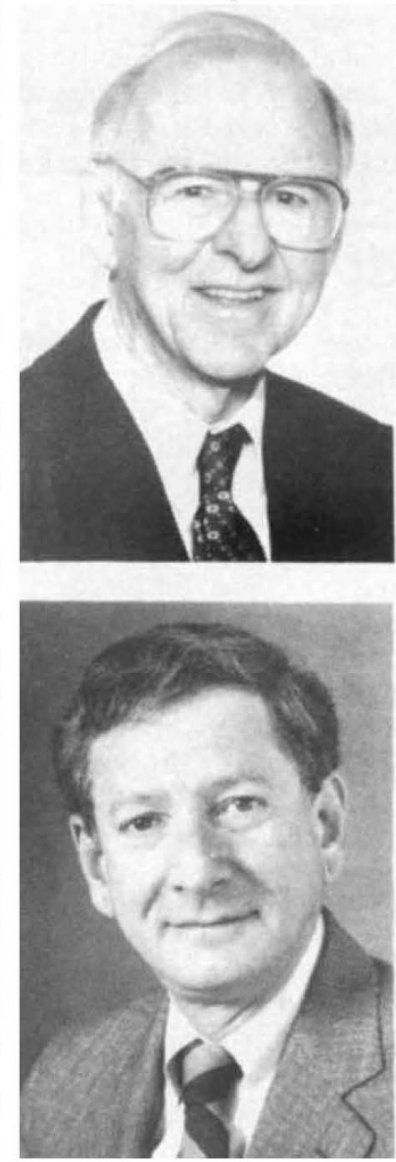

\section{Washington} processes. receptors for progesterone. intake. During the past six months, since the announcement of the cuts, the armed forces have been reduced by 148,900 men.

This figure does not include the 175,700 students, of whom some 168,000 have already returned to their studies. Yazov did not specify the criteria for reducing the intake. Possibly it is being done by raising health requirements. During the past few years, there have been frequent PRIZES complaints about the physique of recruits, of whom almost one in ten fails the medical examination.

The gaps left by the students must once again raise the question of whether it would be more efficient to replace compulsory military service by a smaller, highly trained, professional army.

In the meantime, while the politicians and high command argue costs, much of the Red Army and Navy's most sophisticated equipment is apparently lying idle.

Vera Rich

\section{USA, Japan and UK share research award}
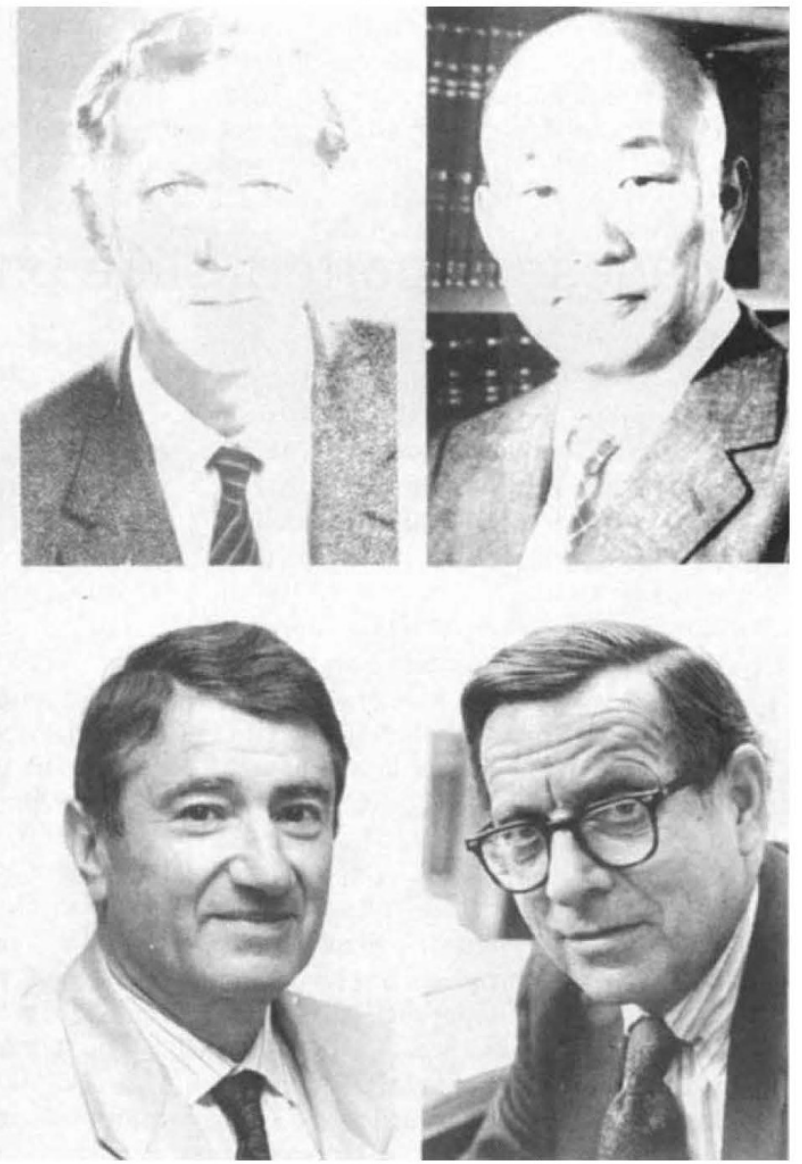

Four scientists share this year's Albert Lasker Basic Medical Research award, which recognizes their four individual discoveries of intracellular signalling pathways. Edwin G. Krebs, of the University of Washington, discovered protein phosphorylation, a fundamental biochemical reaction responsible for the progress of many enzyme reactions; Michael J. Berridge, of the University of Cambridge, was responsible for understanding the importance of calcium in cell growth, and its regulation by inositol triphosphate; Yasutomi Nishizuki, of Kobe University, elucidated the role of the enzyme protein kinase $c$, important in the regulation of both normal and abnormal cell growth; and Alfred G. Gilman, of the University of Texas, discovered Gproteins, a class of proteins that convey information from cell-surface receptors to internal cell

The 1989 Clinical Research Award goes to Etienne-Emile Baulieu of the University of Paris, for his lifelong studies of the biological synthesis and functions of steroid hormones. Baulieu is publicly known for his discovery of the abortifacient drug RU486, which works by blocking the

Lewis Thomas, of Cornell University, adds the 1989 Lasker Public Service Award to a number of book awards, for The Lives of a Cell and The Medusa and the Snail, and numerous honorary degrees. The Lasker citation recognizes Thomas for his promotion of biomedicine and public health not only through his popular writings but also by his activities as an administrator and teacher. Above, from left to right: (top) Edwin Krebs; Michael Berridge; Yasutomi Nishizuki; (bottom) Alfred Gilman; Etienne-Emile Baulieu and Lewis Thomas. 